\title{
AVALIAÇÃo COMPORTAMENTAL E FARMACOLÓGICA DA RELAÇÃO ENTRE ANSIEDADE E PÂNICO EM MODELOS ANIMAIS
}

Bruno de Oliveira Galvão

A MCPD é associada com comportamento defensivo e ataques de pânico em humanos. Estimulações farmacológicas da MCPD induzem a reações aversivas em ratos. No exp. 1, animais submetidos ao medo ao contexto obtiveram resposta de congelamento e menores reações aversivas através da microinjeção de NMDA, comparado ao grupo controle não exposto ao medo ao contexto. No exp. 2, o efeito do PTZ em ratos microinjetados com NMDA nas reações aversivas foi investigado. Os resultados mostraram que o PTZ minimizou as reaçōes aversivas induzidas pela microinjeção de NMDA na MCPD. Os resultados sugerem que a ativação de mecanismos cerebrais que permeiam a ansiedade inibem os ataques de pânico.

\section{BANCA}

Jesus Landeira Fernandez (Orientador)

Guilherme Gutman Correa de Araujo

Luiz de Gonzaga Gawryszewski

Data de defesa: 23/11/2007 